\title{
Folk uses and pharmacological properties of Casearia sylvestris: a medicinal review
}

\author{
PAULO MICHEL P. FERREIRA ${ }^{1}$, LetíCIA V. COSTA-LOTUFO ${ }^{2}$, MANOEL O. MORAES ${ }^{2}$, \\ FRANCISCO W.A. BARROS ${ }^{2}$, ALINE M.A. MARTINS ${ }^{2}$, ALBERTO J. CAVALHEIRO ${ }^{3}$, \\ VANDERLAN S. BOLZANI ${ }^{3}$, ANDRÉ G. SANTOS ${ }^{4}$ and CLÁUDIA PESSOA ${ }^{2}$ \\ ${ }^{1}$ Departamento de Ciências Biológicas, Campus Senador Helvídio Nunes de Barros, \\ Universidade Federal do Piauí, Rua Cícero Eduardo, 905, 64600-000 Picos, PI, Brasil \\ ${ }^{2}$ Departamento de Fisiologia e Farmacologia, Faculdade de Medicina, Universidade Federal do Ceará, \\ Rua Cel. Nunes de Melo, 1127, 60430-270 Fortaleza, CE, Brasil \\ ${ }^{3}$ Núcleo de Bioensaios, Biossíntese e Ecofisiologia de Produtos Naturais, Instituto de Química, \\ Universidade Estadual Paulista, Rua Francisco Degni, s/n, 14800-900 Araraquara, SP, Brasil \\ ${ }^{4}$ Laboratório de Farmacognosia, Departamento de Princípios Ativos Naturais e Toxicologia, \\ Faculdade de Ciências Farmacêuticas, Universidade Estadual Paulista, \\ Rodovia Araraquara, Jaú, Km 1, 14801-902 Araraquara, SP, Brasil
}

Manuscript received on December 21, 2009; accepted for publication on May 19, 2011

\begin{abstract}
Folk uses and scientific investigations have highlighted the importance of Casearia sylvestris extracts and their relevant bioactive potential. The aim of this work was to review the pharmacological properties of C. sylvestris, emphasizing its anti-ulcer, anti-inflammatory, anti-ophidian and antitumor potentialities. Ethanolic extracts and essential oil of their leaves have antiulcerogenic activity and reduce gastric volume without altering the stomach $\mathrm{pH}$, which corroborates their consumption on gastrointestinal disorders. Leaf water extracts show phospholipase $\mathrm{A}_{2}$ inhibitory activity that prevents damage effects on the muscular tissue after toxin inoculation. This antiphospholipasic action is probably related to the use as an anti-inflammatory, proposing a pharmacological blockage similar to that obtained with non-steroidal anti-inflammatory drugs on arachidonic acid and cyclooxygenase pathways. Bioguided-assay fractionations lead to the identification of secondary metabolites, especially the clerodane diterpenes casearins (A-X) and casearvestrins (A-C), compounds with a remarkable cytotoxic and antitumor action. Therefore, the $C$. sylvestris shrub holds a known worldwide pharmacological arsenal by its extensive folk utilization, exciting searches for new molecules and a better comprehension about biological properties.
\end{abstract}

Key words: Casearia sylvestris, folk uses, pharmacological properties.

\section{INTRODUCTION}

The phytotherapic use has increased in developing and in developed countries as an additional way to treat and prevent diseases, particularly chronic illnesses, such as cardiovascular and neurodegenerative dysfunctions (World Health Organization 2003, Ferreira et al. 2008). These natural products are represented by teas, powders, extracts, infusions and other sorts of formulations (Balu-

Correspondence to: Cláudia Pessoa

E-mail: cpessoa@ufc.br nas and Kinghorn 2005, Buriol et al. 2009). Although there is a great interest in synthetic techniques, such as combinatorial chemistry, natural product prospection is a continuous source of new drugs, and around $48 \%$ of new chemical entities (NCE) from 1981 to 2002 were natural products or natural product-derived (Newman et al. 2003). In spite of the medicinal importance, the toxicological potential in plants is frequently considered superfluous and dealt with low priority (Junior and Pinto 2005, Ferreira et al. 2007). 
The Brazilian territory embrace the major diversity of plant species in the world, but less than $10 \%$ have been evaluated with respect to their biological characteristics and fewer than 5\% have been subjected to detailed phytochemical studies (Luna et al. 2005). Nowadays, the curative principle of plants is more disseminated in rural areas due to the lack of efficient laboratorial and clinical facilities, where medical services are problematical, complex and financially more expensive (Holetz et al. 2002, Ferreira et al. 2009).

\section{TAXONOMY OF Casearia sylvestris}

Traditionally, Casearia sylvestris Swartz, 1860 (Synonymous: Samyda parviflora L., Casearia parviflora L., Anavinga samyda Gaertn. F.) belongs to the Flacourtiaceae family, which has 89 genus and 1300 species distributed in tropical and temperate regions around the world. Casearia genus includes almost 180 species (Little and Wadsworth 1964, Torres and Yamamoto 1986). Recently, molecular, ecological, chemical and morphological studies associated with phylogenetic approaches of several families, including Flacourticaceae and Salicaceae, led to the birth of the Angiosperm Phylogeny Group (APG), leading to the Flacourtiaceae family extinction and permutation of the majority of its genus to the Salicaceae family, including Casearia (Souza and Lorenzi 2005).

\section{Distribution AND ANATOMIC DEscription OF Casearia sylvestris}

Commonly widespread in the Americas, C. sylvestris is found in Cuba, Antilleans and Porto Rico to Mexico, Brazil, Bolivia, Peru and Argentina (Little and Wadsworth 1964, Instituto de Botanica Darwinion 2002). In Brazil, it is distributed practically throughout the entire territory extension from Amazonas (Tapajós river region) to Rio Grande do Sul states (Torres and Yamamoto 1986, Hack et al. 2005).

Anatomically, its vegetative and reproductive structures are characterized by crystalline inclusions and glandular cells full of essential oils. The leaves are assimetric, smoothes or rough, peciolated, lanceolate, brilliant, with 6-12 cm length and 3-5 cm wide. It presents radiate and protostelic root and the stem is siphonostelic and ectophloic, distinguished by prismatic crystals and druses, mainly in the cortical phloem (Absy and Scavone 1973).
The flowers are small, green, actinomorphic, hypogene and hermaphrodite. They produce imperceptible odor, nectar of easy access and have exposed sexual organs. The plant flourishes in June and August and its fruits ripen from September to November. These fruits are septicidal capsules with seeds involved by red aril (Absy and Scavone 1973, Torres and Yamamoto 1986). Under good conditions, C. sylvestris is capable to flower and fruit in the second year of life, when it reaches about 1 meter in stature (Little and Wadsworth 1964). In Panamá, these species flower even in dry season between August and December (Croat 1978). With a moderate rate of growth, the plant lives at least 20 years. Its natural and artificial propagation usually occurs through seeds and its wood is used as fuel and suitable to build fence, posts, stakes, rustic carpentry and handle tools (Torres and Yamamoto 1986).

Acquainted with the medical importance of several parts of Casearia sylvestris, this work aims to review its folk pharmacological uses, emphasizing its anti-ulcer, anti-inflammatory, anti-ophidian and antitumor potentialities.

\section{Pharmacological Properties}

In Brazil, C. sylvestris is popularly known as "guaçatonga", a word originated from "Tupi-Guarani" language, which indicates its ancient exploitation by native communities. Other folk names are "erva-de-lagarto", "língua-de-tiú", "cafezinho-do-mato", "corta-lengua", bugre herb and wild-coffee (Hoehne 1939, Little and Wadsworth 1964). The Karajá Indian tribe habitually makes a bark maceration to treat diarrhea; other Brazilian tribes crush its roots to care for wounds, leprosy and as anti-ophidian. Natives from the Shipibo-Conibo tribe (Peru) utilize bark decoction for flu and chest colds (Hoehne 1939). Certainly, the antimicrobial action against pathogens as fungi (Aspergilus niger, Saccharomyces cerevisiae, Candida albicans, Candida tropicalis) (Carvalho et al. 1998, Oberlies et al. 2002, Da Silva et al. 2008b) and bacteria (Bacillus subtilis, Bacillus cereus, Staphyloccoccus aureus, Enterococcus faecalis, Salmonella enteriditis) (Chiappeta et al. 1983, Mosaddik et al. 2004, Da Silva et al. 2008b) explains the uses to treat wounds, skin ulcerations and diarrhea.

In the last years, $C$. sylvestris has been exploited in the development of creams against herpes and commercialized in mixed formulations with other plants to 
TABLE I

Folk therapeutic uses of Casearia sylvestris in some countries

\begin{tabular}{|c|c|c|c|}
\hline Part of the plant/Country & Traditional therapeutic use & Preparation/Administration & Reference \\
\hline Aerial part bark, Peru & Diarrhea & Water extract, oral & Duke and Vásquez (1994) \\
\hline Aerial part bark, Brazil & $\begin{array}{l}\text { Fever } \\
\text { Anti-inflammatory } \\
\text { Snakebites } \\
\text { Diarrhea }\end{array}$ & $\begin{array}{l}\text { Decoction, oral } \\
\text { Decoction, oral } \\
\text { Infusion with bark, topic } \\
\text { Maceration, oral }\end{array}$ & $\begin{array}{l}\text { Brandão et al. (1985) } \\
\text { Hirschmann and de Arias (1990) } \\
\text { Ruppelt et al. (1991) } \\
\text { Duke and Vásquez (1994) }\end{array}$ \\
\hline Leaves, Brazil & $\begin{array}{l}\text { Fever } \\
\text { Snakebites, herpes and syphilis } \\
\text { Sexual stimulant } \\
\text { Sedative, tonic, } \\
\text { anti-inflammatory, } \\
\text { skin diseases and diarrhea }\end{array}$ & $\begin{array}{l}\text { Decoction, oral } \\
\text { Decoction, oral } \\
\text { Decoction, oral } \\
\text { Decoction, oral }\end{array}$ & $\begin{array}{l}\text { Brandão et al. (1985) } \\
\text { Hirschmann and de Arias (1990) } \\
\text { Hirschmann and de Arias (1990) } \\
\text { Simões et al. (1999) }\end{array}$ \\
\hline Leaves, India & Snakebite & Infusion & Selvanayahgam et al. (1994) \\
\hline Leaves, Colombia & Ulcers & Hot water extract, topic & Garcia-Barriga (1975) \\
\hline Various parts, Bolivia & $\begin{array}{l}\text { Analgesic, antacid, } \\
\text { anti-inflammatory, anti-ulcer, } \\
\text { antitumor, antiseptic, } \\
\text { cicatrizing, depurative, } \\
\text { haemostatic, snakebite }\end{array}$ & Numerous, oral & Baya (2001) \\
\hline Roots, Brazil & $\begin{array}{l}\text { Body pains } \\
\text { Wounds, leprosy }\end{array}$ & $\begin{array}{l}\text { Decoction, oral } \\
\text { Maceration, oral }\end{array}$ & $\begin{array}{l}\text { Hirschmann and de Arias (1990) } \\
\text { Duke and Vásquez (1994) }\end{array}$ \\
\hline Seeds, Brazil & Leprosy & Oil, topic & Duke and Vásquez (1994) \\
\hline
\end{tabular}

prepare teas and infusions with therapeutical purposes (Camargo et al. 1993, Alves 2000, Simões et al. 1999). An infusion can be easily obtained ( $20 \mathrm{~g}$ of dried leaves per $1 \mathrm{~L}$ of water) for oral consumption (2-3 times/day) together with meals, in case of gastric ulcers or for topical treatment of wounds, burns, rashes, eczema and vitiligo (Blanco 2010).

Table I displays some therapeutic properties of C. sylvestris and Table II shows the biological activities already mentioned by the scientific community.

\section{Anti-ulcer activity}

Ethanolic extracts of C. sylvestris leaves have revealed anti-ulcer properties, a finding that corroborates its wide use in gastrointestinal disorders (Hoehne 1939, Fialho et al. 2010). Basile et al. (1990) showed that ethanolic extract significantly decreases stomach volume $(42 \%)$ in a more efficient way (when compared to misoprostol, $26 \%$ ) and chloride acid $(\mathrm{HCl})$ production in absence of gastric $\mathrm{pH}$ changes, an excellent finding since protein digestion is largely activated in the stomach by pepsin enzymatic action. The pepsin generation from its inactive precursor pepsinogen requires acid $\mathrm{pH}$ (between 1.6-3.2) and its catalytic activity also needs acid environment. Therefore, alkalinization softly up to $\mathrm{pH} 5$ causes enzyme inactivation (Constanzo 2004). Leaf ethanolic extract do not interferes in the aminoacid absorption, displaying an additional advantage when compared to some synthetic drugs as atropine and cimetidine, molecules that arouses gastric $\mathrm{pH}$ alterations (Torregrosa 1997).

C. sylvestris extracts were also capable to prevent early establishment of gastric lesions in stressed rats with efficacy similar to cimetidine and misoprostol, though these drugs have demonstrated greater protection against severe lesions, especially necrotic and hemorrhagic injuries (Aboin et al. 1987). Esteves et al. (2005) demonstrated a decrease in gastric volumes without physiological alterations in $\mathrm{H}^{+}$concentration, emphasizing that essential oils as well as crude extracts of "guaçatonga" leaves have anti-ulcer properties.

Quantitative analyses of the ethanolic extract indicated traces of terpenes (triterpenes and sesquiterpenes), cumarines, tannins (flavonoids) and some volatile oils that play an important role in mucosa protection (Sertié et al. 2000). Flavonoids are phenolic compounds with antioxidant action and strong capacity to inhibit the production of both nitric oxide and the TNF (tumoral necrosis factor) mediators (Kawada et al. 1998). In fact, the antioxidant potential was showed by Menezes et al. (2004) and among all bioactive compounds found 
TABLE II

Biological activities from different parts of Casearia sylvestris.

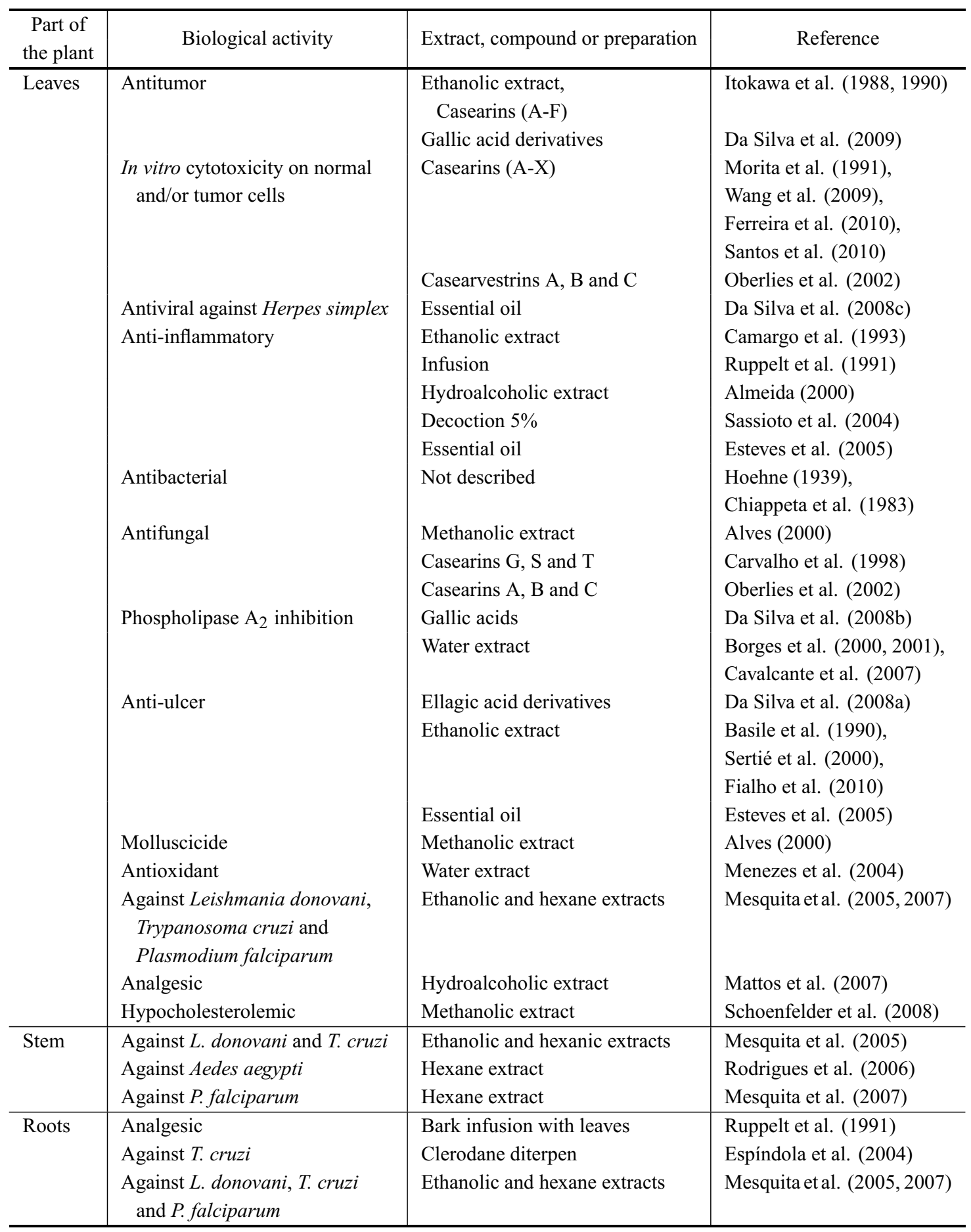

in the ethanolic extract of C. sylvestris, the therapeutic effects of essential oils have been attributed to the biciclogermacrene, a sesquiterpene with anti-inflammatory activity (Abreu Gonzaga et al. 2003). An enriched fraction of diterpenes extracted from leaves of $C$. sylvestris presented antiulcerogenic action in rats in a dose of 
$15.5 \mathrm{mg} / \mathrm{kg} /$ day, inhibiting ulcer formation up to $100 \%$. The clerodane diterpenes casearins B, D, O, X and caseargrewiin $\mathrm{F}$ (Fig. 1) presented the same action in a dose of $1.68 \mathrm{mg} / \mathrm{kg} /$ day. Casearin X was called initially as Casearin U (FAPESP et al. 2003, Santos 2008).

Besides protecting the stomach mucosa, the ethanolic extract shows a $\mathrm{LD}_{50}$ value of $1842 \mathrm{mg} / \mathrm{kg}$ (Basile et al. 1990), a value considered slightly toxic according to toxicity categories established for humans by Hodge and Sterner (1949). Some subacute toxicity assays exhibited promising outcomes, since doses 2.5 fold higher (143.9 mg/kg/day of body weight) show effectiveness as anti-ulcer agent without altering physiological parameters, such as water and food intake, body weight gain and key organ relative weights after thirty days of ethanolic extract oral administration (Basile et al. 1990). Oral acute toxicity (30, 65 and $172 \mathrm{mg} / \mathrm{kg} /$ day) with the compound Casearin $\mathrm{X}$ also did not indicate corporal or behavioral changes, despite the fact that $172 \mathrm{mg} / \mathrm{kg} /$ day is a dose 100-fold higher than $\mathrm{ED}_{100}$ (maximum effective dose) necessary to obtain antiulcerogenic action (1.68 $\mathrm{mg} / \mathrm{kg} /$ day) (FAPESP et al. 2003, Santos 2008).

\section{Anti-inflammatory activity}

Researchers have emphasized the anti-inflammatory potential of substances extracted from "guaçatonga" leaves, attracted by its economical appealing, practical handling and easy folk preparations (Hoehne 1939, Ruppelt et al. 1991).

In some carrageenan-induced inflammation models, the essential oil of $C$. sylvestris leaves inhibited paw edema formation. This proposes a blockage of inflammatory cascade mediators from the arachidonic acid and inhibition of cyclooxygenase (COX) catalytic activity, a property comparable to indomethacin (a nonselective and non-steroidal COX inhibitor). On the other hand, this oil does not interfere on vascular permeability (Esteves et al. 2005) probably due to its failure in antagonizing mastocyte and/or basophile degranulation and discharging of active pharmacological substances (histamine and serotonin, for example) (Tamura et al. 2002).

Decoction of $C$. sylvestris leaves was capable to decrease bone formation possibly because of the pres- ence of anti-inflammatory phytochemical compounds and prostaglandin synthesis inhibition, which may cause inability in macrophage chemotaxis, fibroblast activation and collagen fiber arrangement and formation, with noticeable inhibitory effects on osteogenesis (Sassioto et al. 2004).

\section{Anti-ophidian activity}

In many countries, plant extracts have been traditionally used in the treatment of snake bite poisoning (Martz 1992). Water extract of $C$. sylvestris leaves shows great inhibitory effects on the toxic, enzymatic, hemorrhagic and anticoagulant activities exhibited by various venoms, particularly against those belonging to the PLA 2 I (Phospholipase $\mathrm{A}_{2}$ ) (Elapidae Family), II (Viperidae Family) e III (bee) types (Borges et al. 2000, 2001).

Neuromuscular junction is the main target of snake venoms, some of which possessing strong pre-synaptic neurotoxins, such as the Crotoxin (CTX), a heterotrimeric Asp49-PLA 2 complex found in the Crotalus durissus terrificus venom (Kini 2003). The PLA 2 enzyme activity of CTX is critical for blockage of signal transmission at the endplate. The C. sylvestris antiophidian property seems to be related to the capacity of PLA 2 inhibition (Borges et al. 2000, 2001), which is an enzyme largely activated after venom administration/ inoculation. Aqueous extract of the leaves diminishes injures on skeletal muscle fibers via the prevention of edema formation within endomise (connective tissue) and reduces the muscle blockage, findings responsible by tissue damage protection and enhanced survival rates in extract-pretreated animals depending on the venom class (Cavalcante et al. 2007).

The anti-venom activities of the extract on myotoxins (Bothrops and Crotalus genus) is attributed to their antiphospholipasic action, explaining, at least partially, the anti-inflammatory potential in some clinical circumstances in which there are synthesis and release of prostaglandins and leukotrienes and failure to prevent chronic responses (Esteves et al. 2005). It could be a plausible proposal to assume that the mechanism of action of these compounds may be analogous to nonsteroidal anti-inflammatory drugs.

In view of the fact that the water extract was more efficient in neutralizing hemorrhagic metalloproteinases 


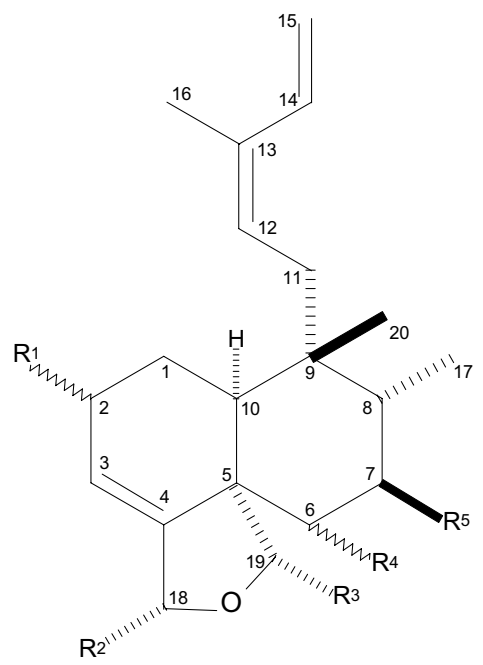

\begin{tabular}{|c|c|c|c|c|c|c|}
\hline Diterpenes & $\mathbf{R}^{1}$ & $\mathbf{R}^{2}$ & $\mathbf{R}^{3}$ & $\mathbf{R}^{4}$ & $\mathbf{R}^{5}$ & $\begin{array}{l}\mathrm{IC}_{50} \\
(\mu \mathrm{M})\end{array}$ \\
\hline Casearin A & $\mathrm{OCH}_{3}(\alpha)$ & $\mathrm{CH}_{3} \mathrm{CO}_{2}$ & $\mathrm{CH}_{3} \mathrm{CO}_{2}$ & $\mathrm{OH}(\alpha)$ & $\mathrm{n}-\mathrm{C}_{3} \mathrm{H}_{7} \mathrm{CO}_{2}$ & 1.0 \\
\hline Casearin B & $\mathrm{OCH}_{3}(\alpha)$ & $\mathrm{CH}_{3} \mathrm{CO}_{2}$ & $\mathrm{CH}_{3} \mathrm{CO}_{2}$ & $\mathrm{CH}_{3} \mathrm{CO}_{2}(\alpha)$ & $\mathrm{n}-\mathrm{C}_{3} \mathrm{H}_{7} \mathrm{CO}_{2}$ & 8.5 \\
\hline Casearin $\mathrm{C}$ & $\mathrm{OH}(\alpha)$ & $\mathrm{CH}_{3} \mathrm{CO}_{2}$ & $\mathrm{CH}_{3} \mathrm{CO}_{2}$ & $\mathrm{CH}_{3} \mathrm{CO}_{2}(\alpha)$ & $\mathrm{n}-\mathrm{C}_{9} \mathrm{H}_{19} \mathrm{CO}_{2}$ & 0.77 \\
\hline Casearin D & $\mathrm{OH}(\alpha)$ & $\mathrm{n}-\mathrm{C}_{3} \mathrm{H}_{7} \mathrm{CO}_{2}$ & $\mathrm{CH}_{3} \mathrm{CO}_{2}$ & $\mathrm{OH}(\alpha)$ & $\mathrm{n}-\mathrm{C}_{3} \mathrm{H}_{7} \mathrm{CO}_{2}$ & 1.8 \\
\hline Casearin E & $\mathrm{OH}(\alpha)$ & $\mathrm{OCH}_{2} \mathrm{CH}_{3}$ & $\mathrm{CH}_{3} \mathrm{CO}_{2}$ & $\mathrm{OH}(\alpha)$ & $\mathrm{n}-\mathrm{C}_{9} \mathrm{H}_{19} \mathrm{CO}_{2}$ & 4.7 \\
\hline Casearin $\mathbf{F}$ & $\mathrm{OH}(\alpha)$ & $\mathrm{OCH}_{2} \mathrm{CH}_{3}$ & $\mathrm{CH}_{3} \mathrm{CO}_{2}$ & $\mathrm{OH}(\alpha)$ & $\mathrm{n}-\mathrm{C}_{3} \mathrm{H}_{7} \mathrm{CO}_{2}$ & 2.9 \\
\hline Casearin G & $\mathrm{OCH}_{3}(\alpha)$ & $\mathrm{CH}_{3} \mathrm{CO}_{2}$ & $\mathrm{CH}_{3} \mathrm{CO}_{2}$ & $\mathrm{H}$ & $\mathrm{n}-\mathrm{C}_{3} \mathrm{H}_{7} \mathrm{CO}_{2}$ & 0.17 \\
\hline Casearin $\mathbf{H}$ & $\mathrm{OH}(\alpha)$ & $\mathrm{CH}_{3} \mathrm{CO}_{2}$ & $\mathrm{CH}_{3} \mathrm{CO}_{2}$ & $\mathrm{H}$ & $\mathrm{n}-\mathrm{C}_{3} \mathrm{H}_{7} \mathrm{CO}_{2}$ & 0.37 \\
\hline Casearin I & $\mathrm{OH}(\alpha)$ & $\mathrm{CH}_{3} \mathrm{CO}_{2}$ & $\mathrm{n}-\mathrm{C}_{3} \mathrm{H}_{7} \mathrm{CO}_{2}$ & $\mathrm{H}$ & $\mathrm{n}-\mathrm{C}_{3} \mathrm{H}_{7} \mathrm{CO}_{2}$ & 0.51 \\
\hline Casearin $\mathbf{J}$ & $\mathrm{OCH}_{3}(\alpha)$ & $\mathrm{n}-\mathrm{C}_{3} \mathrm{H}_{7} \mathrm{CO}_{2}$ & $\mathrm{CH}_{3} \mathrm{CO}_{2}$ & $\mathrm{OH}(\alpha)$ & $\mathrm{n}-\mathrm{C}_{3} \mathrm{H}_{7} \mathrm{CO}_{2}$ & 1.1 \\
\hline Casearin $\mathrm{K}$ & $\mathrm{CH}_{3} \mathrm{CO}_{2}(\alpha)$ & $\mathrm{CH}_{3} \mathrm{CO}_{2}$ & $\mathrm{CH}_{3} \mathrm{CO}_{2}$ & $\mathrm{OH}(\alpha)$ & $\mathrm{n}-\mathrm{C}_{3} \mathrm{H}_{7} \mathrm{CO}_{2}$ & 0.52 \\
\hline Casearin $\mathbf{L}$ & $\mathrm{OCH}_{3}(\alpha)$ & $\mathrm{n}-\mathrm{C}_{3} \mathrm{H}_{7} \mathrm{CO}_{2}$ & $\mathrm{CH}_{3} \mathrm{CO}_{2}$ & $\mathrm{CH}_{3} \mathrm{CO}_{2}(\alpha)$ & $\mathrm{OH}$ & 1.6 \\
\hline Casearin M & $\mathrm{OH}(\alpha)$ & $\mathrm{n}-\mathrm{C}_{3} \mathrm{H}_{7} \mathrm{CO}_{2}$ & $\mathrm{n}-\mathrm{C}_{3} \mathrm{H}_{7} \mathrm{CO}_{2}$ & $\mathrm{CH}_{3} \mathrm{CO}_{2}(\alpha)$ & $\mathrm{OH}$ & 1.8 \\
\hline Casearin N & $\mathrm{OCH}_{3}(\alpha)$ & $\mathrm{CH}_{3} \mathrm{CO}_{2}$ & $\mathrm{n}-\mathrm{C}_{3} \mathrm{H}_{7} \mathrm{CO}_{2}$ & $\mathrm{CH}_{3} \mathrm{CO}_{2}(\alpha)$ & $\mathrm{n}-\mathrm{C}_{3} \mathrm{H}_{7} \mathrm{CO}_{2}$ & 5.9 \\
\hline Casearin $\mathrm{O}$ & $\mathrm{OCH}_{3}(\alpha)$ & $\mathrm{n}-\mathrm{C}_{3} \mathrm{H}_{7} \mathrm{CO}_{2}$ & $\mathrm{CH}_{3} \mathrm{CO}_{2}$ & $\mathrm{CH}_{3} \mathrm{CO}_{2}(\alpha)$ & $\mathrm{n}-\mathrm{C}_{3} \mathrm{H}_{7} \mathrm{CO}_{2}$ & 6.0 \\
\hline Casearin P & $\mathrm{OCH}_{3}(\alpha)$ & $\mathrm{CH}_{3} \mathrm{CO}_{2}$ & $\mathrm{CH}_{3} \mathrm{CO}_{2}$ & $\mathrm{CH}_{3} \mathrm{CO}_{2}(\alpha)$ & $\mathrm{CH}_{3} \mathrm{CO}_{2}$ & 7.8 \\
\hline Casearin Q & $\mathrm{OH}(\alpha)$ & $\mathrm{CH}_{3} \mathrm{CO}_{2}$ & $\mathrm{CH}_{3} \mathrm{CO}_{2}$ & $\mathrm{CH}_{3} \mathrm{CO}_{2}(\alpha)$ & $\mathrm{n}-\mathrm{C}_{3} \mathrm{H}_{7} \mathrm{CO}_{2}$ & 4.3 \\
\hline Casearin $\mathbf{R}$ & $=\mathrm{O}$ & $\mathrm{CH}_{3} \mathrm{CO}_{2}$ & $\mathrm{CH}_{3} \mathrm{CO}_{2}$ & $\mathrm{OH}(\alpha)$ & $\mathrm{n}-\mathrm{C}_{3} \mathrm{H}_{7} \mathrm{CO}_{2}$ & 5.4 \\
\hline Casearin $\mathbf{S}$ & $\mathrm{OCH}_{3}(\alpha)$ & $=0$ & $\mathrm{CH}_{3} \mathrm{CO}_{2}$ & $\mathrm{H}$ & $\mathrm{n}-\mathrm{C}_{3} \mathrm{H}_{7} \mathrm{CO}_{2}$ & - \\
\hline Casearin $T$ & $\mathrm{OCH}_{3}(\alpha)$ & $\mathrm{CH}_{3} \mathrm{CO}_{2}$ & $\mathrm{CH}_{3} \mathrm{CO}_{2}$ & $\mathrm{CH}_{3} \mathrm{CO}_{2}(\beta)$ & $\mathrm{n}-\mathrm{C}_{3} \mathrm{H}_{7} \mathrm{CO}_{2}$ & - \\
\hline Casearin U & $\mathrm{OCH}_{3}(\alpha)$ & $\mathrm{OCH}_{3}$ & $\mathrm{CH}_{3} \mathrm{CO}_{2}$ & $\mathrm{OH}(\alpha)$ & $\mathrm{n}-\mathrm{C}_{3} \mathrm{H}_{7} \mathrm{CO}_{2}$ & - \\
\hline Casearin V & $\mathrm{OH}(\alpha)$ & $\mathrm{OCH}_{3}$ & $\mathrm{CH}_{3} \mathrm{CO}_{2}$ & $\mathrm{OH}(\alpha)$ & $\mathrm{n}-\mathrm{C}_{3} \mathrm{H}_{7} \mathrm{CO}_{2}$ & - \\
\hline Casearin X & $\mathrm{n}-\mathrm{C}_{3} \mathrm{H}_{7} \mathrm{CO}_{2}(\alpha)$ & $\mathrm{n}-\mathrm{C}_{3} \mathrm{H}_{7} \mathrm{CO}_{2}$ & $\mathrm{CH}_{3} \mathrm{CO}_{2}$ & $\mathrm{OH}(\alpha)$ & $\mathrm{H}$ & - \\
\hline Casearvestrin A & $\left(\mathrm{CH}_{3}\right)_{2} \mathrm{CHCO}_{2}(\beta)$ & $\mathrm{CH}_{3} \mathrm{CO}_{2}$ & $\mathrm{CH}_{3} \mathrm{CO}_{2}$ & $\mathrm{OH}(\alpha)$ & $\mathrm{H}$ & - \\
\hline Casearvestrin B & $\mathrm{CH}_{3} \mathrm{CH}_{2} \mathrm{CH}\left(\mathrm{CH}_{3}\right) \mathrm{CO}_{2}(\beta)$ & $\mathrm{CH}_{3} \mathrm{CO}_{2}$ & $\mathrm{CH}_{3} \mathrm{CO}_{2}$ & $\mathrm{OH}(\alpha)$ & $\mathrm{H}$ & - \\
\hline Casearvestrin C & $\mathrm{n}-\mathrm{C}_{5} \mathrm{H}_{11} \mathrm{CO}_{2}(\beta)$ & $\mathrm{CH}_{3} \mathrm{CO}_{2}$ & $\mathrm{CH}_{3} \mathrm{CO}_{2}$ & $\mathrm{OH}(\alpha)$ & $\mathrm{H}$ & - \\
\hline Caseargrewiin F & $\mathrm{n}-\mathrm{C}_{3} \mathrm{H}_{7} \mathrm{CO}_{2}(\alpha)$ & $\mathrm{CH}_{3} \mathrm{CO}_{2}$ & $\mathrm{CH}_{3} \mathrm{CO}_{2}$ & $\mathrm{OH}(\alpha)$ & $\mathrm{H}$ & - \\
\hline
\end{tabular}

Fig. $1-\mathrm{R}^{1}-\mathrm{R}^{5}$ substituents of casearins A-X, caseargrewiin $\mathrm{F}$ and casearvestrins A-C (Carvalho et al. 1998, Itokawa et al. 1990, Morita et al. 1991, Oberlies et al. 2002, Wang et al. 2009, Ferreira et al. 2010, Santos et al. 2010) and cytotoxicity ( $\left.\mathrm{IC}_{50}\right)$ on Chinese hamster V-79 cells of casearins A-R (adapted from Morita et al. 1991). 
from bothropic venoms than neutralize serina-proteases, it is proposed that this extract may act as a metal natural chelating (Borges et al. 2001). Other possibility would be linkage of the active compound, present in the extract, to the enzyme catalytic site which could avoid coupling of the substrate to the enzyme in a covalent or non-covalent interaction way. Highly reactive tannins presented in the leaves can bind to biological polymers and enzymes, allowing the electron transportation and obstructing the enzymatic activity (Abdulla and Gruber 2000, Delfino and Canniatti-Brazaca 2010).

Four ellagic acid derivatives from aqueous extracts of $C$. sylvestris were isolated, characterized and tested against actions of both total venom and PLA 2 (Asp 49 BthTX-II) from Bothrops jararacussu venom. The isolated compounds were ellagic acid, $3^{\prime}$ - $O$-methyl ellagic acid, 3,3'-di- $O$-methyl ellagic acid and 3-O-methyl$3^{\prime}, 4^{\prime}$-methylenedioxy ellagic acid. The constant inhibition values for enzymatic activity as well the $\mathrm{IC}_{50}$ values found in the edematogenic and myotoxic activities indicate that the ellagic acid is the best inhibitor of these activities. The results show that the presence of hydroxyls at position 3 or $3^{\prime}$ increase the capacity of these derivatives on inhibiting toxic effects. However, the existence of methoxyl groups at position 3 or $3^{\prime}$ reduced but did not completely inhibit the capacity of compounds on reducing all the toxic effects studied (Da Silva et al. 2008a).

\section{Antitumor activity}

Most of the compounds isolated from Casearia leaves are represented by a series of oxygenated tricyclic cisclerodane diterpenes in which the tetrahydrofuran ring is C-acylated at positions C-18 and C-19 (Fig. 1). The diacetalic ring is a highly oxygenated structure rarely seen in natural molecules, being a protected dialdehyde (Santos et al. 2007). Bioguided fractionation assays have regularly revealed that clerodane diterpenes, predominantly those rich in oxygen atoms, possess antifungal, antibacterial, insecticidal, antifeedant and cytotoxic properties (Morita et al. 1991, Merrit and Ley 1992, Oberlies et al. 2002, Vieira-Junior et al. 2009).

Twenty eight clerodane diterpenes typical of Casearia were isolated from C. sylvestris: casearins A-X (Carvalho et al. 1998, Itokawa et al. 1990, Morita et al. 1991, Wang et al. 2009, Santos et al. 2010) and caseargrewiin F (Santos et al. 2010), isolated from leaves; casearvestrins A-C, isolated from leaves and branches (Oberlies et al. 2002); and rel-19S-acetoxy-18R-butanoyloxy-18,19-epoxy- $6 S$-hidroxy-2R-(2-methylbutanoyloxy) $-5 S, 8 R, 9 R, 10 S$-cleroda-3,13(16),14-triene, isolated from roots (Espíndola et al. 2004) (Fig. 1).

Casearins and their biological activities show structure-activity relationship largely attributed to the diterpene skeleton substitutions at positions $\mathrm{C}-2\left(\mathrm{R}^{1}\right), \mathrm{C}-6$ $\left(R^{4}\right), C-7\left(R^{5}\right), C-18\left(R^{2}\right)$ and $C-19\left(R^{3}\right)$. Figure 1 describes the cytotoxic activity of the casearins on Chinese hamster V-79 cells. Casearins G, H and I, whose structures are characterized by the oxygen-bearing function absence at C-6, showed the highest antiproliferative activity, followed by the diterpenes $\mathrm{J}, \mathrm{K}, \mathrm{L}$ and $\mathrm{M}$, whose structures present hydroxyl moiety at C-6 or C-7. Other casearins, as N, O, P, Q and R have weaker activity, which seems to be determined by methoxyl, hydroxyl or oxygen substituents of $\mathrm{R}^{1}$. Derivatives converted from the casearins A and D by inducement of acyl substituent at C-6 exerted decrease in the cytotoxicity (Morita et al. 1991), demonstrating that bulkiness at C-6 has the highest influence on the bioactivity. Such cytotoxicity on cancer cells was also found in the $C$. sylvestris leaf oil (Da Silva et al. 2008c), whose composition previously reported exhibits two well characterized cytotoxic sesquiterpenes ( $\beta$-caryophyllene e a-humulene) (Tatman and Mo 2002, Esteves et al. 2005, Sylvestre et al. 2005).

Although the cytotoxic mechanism is unclear, Carvalho et al. (1998) reported that clerodane diterpenes G, $\mathrm{S}$ and $\mathrm{T}$ can cause acetylating on DNA molecule. Recently, this toxicity on DNA molecules was confirmed by Ferreira et al. (2010) who showed that Casearin X causes DNA and nuclear fragmentation, phosphatidylserine externalization, activation of the effector caspases $3 / 7$ and mitochondrial depolarization in leukemia cells, all evidences of apoptosis cell death. Caspases, cysteineproteases with ability to cause cleavages on laminin and changes on DNA structure triggered by DNAses lead to cytoskeleton and nuclear destabilization and chromatin fragmentation and condensation. Eventually, cells become divided in apoptotic bodies full of organelles and/or nuclear material surrounded by integral plasma membrane. Immediately, the largest part of the bodies is engulfed by macrophages. Thus, since there is no 
intracellular factor releasing, apoptosis occurs without immune system activation (Strasser et al. 2000).

Ethanolic extract phytochemical investigations of C. sylvestris leaves reported strong antitumor activity on Sarcoma 180 transplanted mice (100 mg/kg/dia), with tumor growth inhibition rates higher than $80 \%$ (Itokawa et al. 1988). Bioguided studies led to the isolation of six pharmacologically active compounds, the casearins $\mathrm{A}, \mathrm{B}, \mathrm{C}, \mathrm{D}, \mathrm{E}$ and F. Additional in vivo experiments $(15 \mathrm{mg} / \mathrm{kg} /$ day) confirmed the antineoplasic action of these clerodanes, though casearin $\mathrm{C}$ has showed better antiproliferative effects. The main structural difference among these six diterpenes is the presence of a casearin C decanoate substituent at C-7 (Fig. 1), which could explain its higher cytotoxicity on V-79 cells (Itokawa et al. 1990) likely based on its remarkably larger hydrophobicity and facility to penetrate cytoplasm membrane cell.

Recently, two gallic acid-derived compounds isolated from $C$. sylvestris leaves - isobutyl gallate-3,5dimethyl ether (IGDE) and methyl gallate-3,5-dimethyl ether (MGDE) - showed significant chemotherapeutic potential against Ehrlich and Lewis lung cancer ascite tumor cells and increased animals' survival by approximately $90 \%$, though IGDE possesses a slightly superior activity when compared to MGDE (Da Silva et al. 2009). Hydroxybenzoic acids, such as gallic and ellagic acids as well as other polyphenolic molecules possess cytotoxic activity on human cancer cells (Zhang et al. 2005, Veluri et al. 2006). In addition, other researches have reported that plants with polyphenolic substances (for instance, flavonoids) protect the cells against injury caused by X-rays, block the progression of the cell cycle and prostaglandin synthesis, inhibit mutations and prevent carcinogenesis in experimental animals (Abdulla and Gruber 2000).

Detailed studies revealed that MGDE and IGDE induce higher levels of splenic natural killer (NK) cell in tumor-bearing mice (Da Silva et al. 2009). During Erlich ascites tumor growth, the level of NK cell activity in the spleen frequently decreases, which is important for tumor proliferation, since NK cells and cytokines (interleukin-2 and interferon- $\gamma$ ) inhibits the growth of this murine tumor model (Valadares et al. 2003). Moreover, evidences show role of interferon- $\gamma$ in macrophage-mediated regulation of host anti-tumor responses
(Yamamoto et al. 1995). Then, the anticancer potential exhibited by MGDE and IGDE might be related to the modulation of the immunologic system as a result of enhancement in NK cell activity in tumor-bearing mice. Therefore, many researches have highlighted the in vitro and in vivo antiproliferative capacity from clerodane diterpenes of $C$. sylvestris on tumor cells, very important discoveries that emphasize this plant as an important natural source of leading molecules.

Besides this antitumor potentiality, different parts of the plant also exhibit activity against Leishmania donovani promastigotes (Mesquita et al. 2005), Trypanosoma cruzi amastigotes (Espíndola et al. 2004, Mesquita et al. 2005), Plasmodium falciparum strains resistant to chloroquine (Mesquita et al. 2007) and Aedes aegypti larvae (Rodrigues et al. 2006). Leaf methanolic extract shows anti-hyperlipidemic properties, decreasing serum triglycerides and lipases (Schoenfelder et al. 2008) and the water extract displays neuromodulatory effects on central nervous system by the interference on enzymatic action of the purinergic and cholinergic systems since it inhibits $\mathrm{Na}^{+}-/ \mathrm{K}^{+} /$ATPase and $5^{\prime}$-nucleotidase activities (Silva et al. 2006). Additionally, the hydroalcoholic extract has antinociceptive capability likely due to the inhibition of an inflammatory mediator and/or by the activation of opioid cascade (Mattos et al. 2007).

\section{CONCLUSION}

Several reports have highlighted the medicinal value of extracts and compounds isolated from Casearia sylvestris, underscoring a worthy pharmacological arsenal to this plant, bringing evidence to its worldwide popular use and encouraging further searches for novel bioactive molecules and a better comprehension about its bioactivities.

\section{ACKNOWLEDGMENTS}

We wish to thank Conselho Nacional de Desenvolvimento Científico e Tecnológico (CNPq), Coordenação de Aperfeiçoamento de Pessoal de Nível Superior (CAPES), Financiadora de Estudos e Projetos (FINEP), Fundação de Amparo à Pesquisa do Estado de São Paulo (FAPESP) and Banco do Nordeste do Brasil (BNB) for financial support in the form of grants and fellowship awards. 


\section{RESUMO}

Usos populares e pesquisas científicas têm destacado a importância dos extratos da planta Casearia sylvestris e seu grande potencial bioativo. Neste trabalho, objetiva-se revisar as propriedades farmacológicas de C. sylvestris, enfatizando sua potencialidade antiulcerogênica, antiinflamatória, antiofídica e antitumoral. O extrato etanólico e o óleo essencial das folhas possuem atividade antiulcerogênica promissora, diminuindo o volume gástrico sem alterar o $\mathrm{pH}$ estomacal, corroborando sua aplicação contra dores gastrointestinais. Já os extratos aquosos das folhas têm atividade inibitória contra fosfolipase $\mathrm{A}_{2}$ presente em venenos de cobras, atenuando os efeitos lesivos sobre a musculatura esquelética resultantes da inoculação das toxinas. Essa ação antifosfolipásica provavelmente está relacionada ao seu uso como antiinflamatório, sugerindo um bloqueio análogo ao dos fármacos antiinflamatórios não-esteroidais na formação de mediadores oriundos do ácido araquidônico e na ativação da ciclooxigenase. Ensaios de fracionamento bioguiado dos extratos culminaram no isolamento e identificação de inúmeros metabólitos secundários, especialmente os diterpenos clerodânicos casearinas (A-X) e casearvestrinas (AC), compostos que têm surpreendido por sua ação citotóxica e antitumoral. Assim, a planta C. sylvestris apresenta um enorme arsenal farmacológico já mundialmente comprovado por seu vasto uso popular, estimulando pesquisas por novas moléculas e a busca pela compreensão de suas propriedades biológicas.

Palavras-chave: Casearia sylvestris, uso popular, propriedades farmacológicas.

\section{REFERENCES}

ABDUlla M AND GRUBer P. 2000. Role of diet modification in cancer prevention. Biofactors 12: 45-51.

Aboin E, Arquero P And Balboa V. 1987. Prostaglandina PGE, análogo sintético misoprostol no manuseio de lesões de mucosa gástrica induzidas por etanol. Arq Bras Med 61: 277-283.

Abreu Gonzaga W, Weber AD, Giacomelli SR, Simionatto E, Dalcol II, Dessoy EC AND Morel AF. 2003. Composition and antibacterial activity of the essential oils from Zanthxylum rhoifolium. Planta Med 69: $773-775$.

Absy ML and Scavone O. 1973. Sobre a morfologia e anatomia de Casearia sylvestris Swarts. Bol Zool Biol Mar 30: 641-676.

AlmeidA A. 2000. Atividades anti-inflamatória e antitumoral do extrato hidroalcoólico de Casearia sylvestris: estudo comparativo com os antiinflamatórios piroxicam e meloxicam. São Paulo, 97 p. Tese de Doutorado - Instituto de Ciências Biomédicas, Universidade de São Paulo.

ALVES TMA. 2000. Biological screening of Brazilian medicinal plants. Mem Inst Osw Cruz 95: 363-373.

BALUNAS MJ AND Kinghorn AD. 2005. Drug discovery from medicinal plants. Life Sci 78: 431-441.

Basile AC, Sertié JAA, Panizza S, Oshiro TT AND AzZOLINI CA. 1990. Pharmacological assay of Casearia sylvestris. I: Preventive anti-ulcer activity and toxicity of the leaf crude extract. J Ethnopharmacol 30: 185-197.

BAYA A. 2001. Descripcion Taxonomica de Especies utilizadas como Medicinales en el Tropico de Cochabamba. Cochabamba: Universidad Privada del Valle, Cochabamba, Boliva, 111 p.

BLANCO RA. 2010. Guaçatonga (Casearia sylvestris). Disponível em:

<http: www.jardimdeflores.com.br/ERVAS/A34guacatonga.htm> Acesso em: 01 dez. 2010.

Borges MH, SoAres AM, Rodrigues VM, Oliveira F, Franshechi AM, Rucavado A, Giglio JR And Homsi-BRANDEBURGO MI. 2001. Neutralization of proteases from bothrops snake venoms by the aqueous extract from Casearia sylvestris (Flacourtiaceae). Toxicon 39: 1863-1869.

Borges MH, SOARES AM, Rodrigues VM, QUiNTEro A, Lizano S, Gutiérrez JM, Giglio JR AND HoMSI-BRANDEBURGo MI. 2000. Effects of aqueous extract of Casearia sylvestris (Flacourtiaceae) on actions of snake and bee venoms and on activity of phospholipases $A_{2}$. Comp Biochem Physiol 127: 21-30.

Brandẽo M, Botelho M ANd Krettli E. 1985. Antimalarial experimental chemotherapy using natural products. Cienc Cult 37: 1152-1163.

BURIOL L ET AL. 2009. Composição química e atividade biológica de extrato oleoso de própolis: uma alternativa ao extrato etanólico. Quim nova 32: 296-302.

Camargo FG, Gomes E, Pannunzio E and Bueno VS. 1993. Uso tópico do extrato fluido de folha de guaçatonga (Casearia sylvestris Swarts) topicamente em lesões de estomatite herpética. Brag Pta 1: 121-127.

Carvalho PRF, Furlan M, Young MCM, Kingston DGI AND BolZANI VS. 1998. Acetylated DNA-damaging clerodane diterpenes from Casearia sylvestris. Phytochem 49: 1659-1662.

Cavalcante Wlg, Camposa tO, Pai-Silva MD, Pereira OS, Oliveira CZ, Soares AM and GalLACCI M. 2007. Neutralization of snake venom phospholipase $A_{2}$ toxins by aqueous extract of Casearia sylvestris 
(Flacourtiaceae) in mouse neuromuscular preparation. J Ethnopharmacol 112: 490-497.

Chiappeta ADA, de Mello JF and Maciel GM. 1983. Higher plants with biological activity - Plants of Pernambuco. Rev Inst Antibiot 21: 43-50.

Constanzo LS. 2004. Physiology. Virginia: WB Saunders, $480 \mathrm{p}$.

CROAT TB. 1978. Flora of Barro Colorado Island. Stanford: University Press, 943 p.

Da Silva SL, Calgarotto AK, ChaAr JS AND MARANGONI S. 2008a. Isolation and characterization of ellagic acid derivatives isolated from Casearia sylvestris Sw. aqueous extract with anti-PLA 2 activity. Toxicon 52: 655-666.

Da Silva SL, ChaAr JS, Damico DCS, Figueiredo PMS AND YANO T. 2008b. Antimicrobial activity of ethanol extract from leaves of Casearia sylvestris. Pharm Biol 46: 347-351.

Da Silva SL, ChaAr JS, Figueiredo PMS and Yano T. 2008c. Cytotoxic evaluation of essential oil from Casearia sylvestris Sw on human cancer cells and erythrocytes. Acta Amazonica 38: 107-112.

Da Silva SL, ChaAr JS And Yano T. 2009. Chemotherapeutic potential of two gallic acid derivative compounds from leaves of Casearia sylvestris Sw (Facourtiaceae). Eur J Pharmacol 608: 76-83.

DElFino RA AND CANNiATti-BrazaCA SG. 2010. Interação de polifenóis e proteínas e o efeito na digestibilidade protéica de feijão comum (Phaseolus vulgaris L.) cultivar Pérola. Cienc Tecnol Aliment 30: 308-312.

Duke JA AND VÁsquez R. 1994. Amazonian Ethnobotanical Dictionary. Boca Raton: CRC Press, 215 p.

Espíndola LS, VAsconcelos-JUnior JR, DE MESQuita ML, Marquie P, de Paula Je, Mambu L and SANTANA JM. 2004. Trypanocidal activity of a new diterpene from Casearia sylvestris var. lingua. Planta Med 70: 1093-1095.

EsteVES I ET AL. 2005. Gastric anti-ulcer and anti-inflammatory activities of the essential oil from Casearia sylvestris Sw. J Ethnorpharmacol 101: 191-196.

FAPESP - FUNDAÇÃO DE AMPARO À PESQUISA DO Estado de SÃo PaUlo. 2003. Universidade Estadual Paulista (UNESP) and Universidade de São Paulo (USP) (Brasil). Sertié JAA, Woisky RG, Cavalheiro AJ, Bolzani VS, Santos AG and Tininis AG. 18 dez. 2003. Processo de obtenção de extratos de Casearia sylvestris, processos de obtenção de frações ativas, extratos, frações ativas, uso de extratos e frações ativas, composição, unidade de dosagem, método para prevenir, tratar, combater ou suspender distúrbios gastrointestinais, medicamento e princípio ativo. Patente $\mathrm{N}^{\circ}$ PI 0306167-1.

Ferreira PMP, CARVAlHo AFFU, Farias DF, CARIoLANo NG, Melo VMM, Queiroz MGR, Martins AMC And Machado-Neto JG. 2009. Larvicidal activity of the water extract of Moringa oleifera seeds against Aedes aegypti and its toxicity upon laboratory animals. An Acad Bras Cienc 81: 207-216.

Ferreira PMP, Carvalho AFFU, Sousa DF, MagaLHÃEs JF, MARTINS AR, MARTINS MAC AND QUEIROZ MGR. 2007. Water extract of Moringa oleifera seeds: a toxicological approach. REPM 1: 45-57.

Ferreira PMP, Farias DF, Oliveira JTA and CARVALHO AFFU. 2008. Moringa oleifera: Bioactive compounds and nutritional potential. Rev Nutr 21: 431-437.

Ferreira PMP, Santos AG, Tininis AG, Costa PM, Cavalheiro AJ, Bolzani VS, Moraes MO, Costa-Lotufo LV, Montenegro RC and Pessoa C. 2010. Casearin $X$ exhibits cytotoxic effects in leukemia cells triggered by apoptosis. Chem Biol Interact 188 : 497-504.

Fialho SS, Nogueira GM, Duarte CA, Neto AOP AND MACORIS DG. 2010. Casearia sylvestris on gastric permeability to sucrose in horses submitted to gastric ulcer induction protocol. Cienc Rural 40: 348-355.

GARCIA-BARriga H. 1975. Flora Medicinal de Colombia. Santa Fé de Bogotá: Universidad Nacional de Colombia, Talleres Editoriales de la Imprensa Nacional.

Hack C, Longhi SJ, Boligon AA, Murari AB AND PAUleski DT. 2005. Análise fitossociológica de uma fragmento de floresta estacional decidual no município de Jaguari, RS. Cienc Rural 35: 1083-1091.

HIRSCHMANN GS AND DE ARIAS AR. 1990. A survey of medicinal plants of Minas Gerais, Brazil. J Ethnopharmacol 29: 159-172.

Hodge HC AND STERner JH. 1949. Tabulation of toxicity classes. Am Ind Hyg Assoc 10: 93-96.

HoEHne FC. 1939. Plantas e substâncias vegetais tóxicas e medicinais. São Paulo: Graphicars, 355 p.

Holetz FB, Pessini GL, Sanches NR, Cortez DA, NAKAMURA CV AND Filho BP. 2002. Screening of some plants used in the Brazilian folk medicine for the treatment of infectious diseases. Mem Inst Osw Cruz 97: 1027-1031.

Instituto De BotanicA DARwinion. 2002. Catálogo de las plantas vasculares de la Argentina: Flacourtiaceae. Disponível em: <http://www.darwin.edu.ar $>$. Acesso em: 11 abr. 2009. 
ITOKAWA H, TOTSUKA N, MORITA HN, TAKEyA K, IITAKA Y, SCHENKEL EP AND Montidome M. 1990. New antitumor Principles, Casearins A-F, from Casearia sylvestris Sw. (Flacourtiaceae). Chem Pharm Bull 38: 3384-3388.

Itokawa H, Totsuka N, TAKeya K, Watanabe K AND OBATA E. 1988. Antitumor principles from Casearia sylvestris Sw. (Flacourtiaceae), structure elucidation of new clerodane diterpenes by 2D NMR spectroscopy. Chem Pharm Bull 36: 1585-1588.

JUNIOR VFV AND PINTO AC. 2005. Plantas medicinais: cura segura? Quim Nova 28: 519-528.

Kawada N, SeKi S, InOue M And Kuroki T. 1998. Effect of antioxidants, resveratrol, quercetin, and $\mathrm{N}$-acetylcysteine on the functions of cultured rat hepatic stellate cells and Kupfer cells. Hepatol 27: 1265-1274.

KINI RM. 2003. Excitement ahead: structure, function and mechanism of snake venom phospholipase $\mathrm{A}_{2}$ enzymes. Toxicon 42: 827-840.

LitTle EL AND WADSWORTH FL. 1964. Common trees of Puerto Rico and Virgin Islands. Washington: Department of Agriculture, $548 \mathrm{p}$.

Luna JS, Santos AF, Lima MrF, Omena MC, MenDONÇA FAC, BIEBER LW AND SANT'ANA AEG. 2005. A study of the larvicidal and molluscicidal activities of some medicinal plants from Northeast Brazil. J Ethnopharmacol 97: 199-206.

MARTZ W. 1992. Plant with a reputation against sankebite. Toxicon 30: 1131-1142.

Mattos ES, Frederico MJS, Colle TD, Pieri DV AND Peters RR. 2007. Piovezan, A.P. Evaluation of antinociceptive activity of Casearia sylvestris and possible mechanism of action. J Ethnopharmacol 112: 1-6.

Menezes PR, Schwarz EA AND SAnTos CAM. 2004. In vitro antioxidant activity of species collected in Paraná. Fitoterapia 75: 398-400.

MERRIT AT AND LEY SV. 1992. Clerodane diterpenoids. Nat Prod Rep 9: 243-287.

Mesquita ML, Desrivot J, Bories C, Fournet A, Paula JE, Grellier P AND Espíndola LS. 2005. Antileishmanial and trypanocidal activity of Brazilian Cerrado plants. Mem Inst Osw Cruz 100: 783-787.

Mesquita ML, Grellier P, Mambu L, de Paula Je AND ESPÍNDOLA LS. 2007. In vitro antiplasmodial activity of Brazilian Cerrado plants used as traditional remedies. J Ethnopharmacol 110: 165-170.

Morita H, Nakayama M, Kojima H, Takeya K, ItoKAWA H, SChenkel EP AND Motidome M. 1991.
Structure and cytotoxic activity relationship of casearins, new clerodane diterpenes from Casearia sylvestris Sw. Chem Pharm Bull 39: 693-697.

Mosaddik MA, Banbury L, Forster P, Booth R, Markham J, Leach D AND Waterman PG. 2004. Screening of some Australian Flacourtiaceae species for in vitro antioxidant, cytotoxic and antimicrobial activity. Phytomed 11: 461-466.

Newman DJ, Cragg GM and Snader KM. 2003. Natural products as a source of new drugs over the period 1981-2002. J Nat Prod 66: 1002-1037.

OBERLIES NH ET AL. 2002. Novel bioactive clerodane diterpenoids from the leaves and twigs of Casearia sylvestris. J Nat Prod 65: 95-99.

Rodrigues AMS, de Paula Je, Degallier N, Molez JF AND ESPÍNDOLA LS. 2006. Larvicidal activity of some Cerrado plant extracts against Aedes aegypti. J Am Mosq Control Assoc 22: 314-317.

Ruppelt BM, Pereira EFr, Gonçaves LC ANd PeREIRA NA. 1991. Pharmacological screening of plants recommended by folk medicine as anti-snake venom I. Analgesic and anti-inflammatory activities. Mem Inst Osw Cruz 86: 203-235.

SANTOS AG. 2008. Identificação dos princípios ativos antiulcerogênicos das folhas de Casearia sylvestris: contribuição para o desenvolvimento de um fitoterápico. Tese (Doutorado em Química) - Instituto de Química, Universidade Estadual Paulista, 361 p.

SAntos AG, FERreira PMP, VieIra-Júnior GM, Perez CC, Tininis AG, Silva GH, Bolzani VS, Costa-Lotufo LV, Pessoa C And Cavalheiro AJ. 2010. Casearin X, its degradation product and other clerodane diterpenes from leaves of Casearia sylvestris: evaluation of cytotoxicity against normal and tumour human cells. Chem Biod 7: 205-215.

Santos AG, Perez CC, Tininis AG, Bolzani VS And CAVAlheiro AJ. 2007. Clerodane diterpenes from leaves of Casearia sylvestris Swartz. Quim Nova 30: 1100-1103.

SAssioto MCP, Filho NC, FACCO GG, Sodré ST, Neves N, Purisco SU And Farias AG. 2004. Efeito da Casearia sylvestris no reparo ósseo com matriz óssea bovina desvitalizada em ratos. Acta Cir Bras 19: 637-641.

Schoenfelder T, Pich CT, Geremias R, Ávila S, Daminelli EM, Pedrosa RC And Bettiol J. 2008. Antihyperlipidemic effect of Casearia sylvestris methanolic extract. Fitoterapia 79: 465-467.

SElvanAYAhGAM ZE, GNANEVENDHAN SG AND BALAKRISHNA K. 1994. Antisnake venom botanicals from ethnomedicine. J Herbs Spices Med Plants 2: 45-100. 
Sertié JAA, Carvalho JCT and Panizza S. 2000. Antiulcer activity of crude extracts from leaves of Casearia sylvestris. Pharm Biol 38: 112-119.

Silva AC, Balz D, De Souza JBD, Morsc VM, CorRÊA MC, ZANetTi GD, MANFron MP AND SCHETINGER MRC. 2006. Inhibition of NTPDase, 50-nucleotidase, $\mathrm{Na}^{+} / \mathrm{K}^{+}$-ATPase and acetylcholinesterase activities by subchronic treatment with Casearia sylvestris. Phytomed 13: 509-514.

Simões CMO, Amoros M ANd GirRe L. 1999. Antiviral activity of South Brazilian medicinal plant extracts. Phytomed 6: 205-214.

Souza VC And Lorenzi H. 2005. Botânica Sistemática - Guia ilustrado para identificação das famílias de Angiospermas da flora brasileira, baseado em APG II. São Paulo: Nova Odessa - Instituto Plantarum, 640 p.

Strasser A, O'CONNOR L ANd Dixit VM. 2000. Apoptosis signaling. Annu Rev Biochem 69: 217-245.

Sylvestre M, Legault J, Dufour D and Pichette A. 2005. Chemical composition and anticancer activity of leaf essential oil of Myrica gale L. Phytomed 12: 299-304.

TAmura T, Shirai T, Kosaka N, OHmori K AND TAKaFUMI N. 2002. Pharmacological studies of diacerein in animal models of inflammation arthritis and bone resorption. Eur J Pharmacol 448: 81-87.

TATMAN D AND Mo H. 2002. Volatile isoprenoid constituents of fruits, vegetables and herbs cumulatively suppress the proliferation of murine B16 melanoma and human HL-60 leukemia cells. Cancer Letters 175: 129-139.

Torregrosa Z. 1997. Risco Anestésico da Cirurgia de Urgência. Rev Bras Anestesiol 44: 249-258.
TORRES RB And YAmamoto K. 1986. Taxonomia das espécies de Casearia Jacq. (Flacourtiaceae) do estado de São Paulo. Rev Bras Bot 9: 239-258.

VAladares MC, KLein SI, Guaraldo AMA AND QUeIROZ MLS. 2003. Enhancement of natural killer cell function by titanocenesin mice bearing Ehrlich ascites tumor. Eur J Pharmacol 473: 191-196.

Veluri R, Singh RP, LiU Z, Thompson JA, Agarwal R AND AGARWAL C. 2006. Fractionation of grape seed extract and identification of gallic acid as one of the major active constituents causing growth inhibition and apoptotic death of DU145 human prostate carcinoma cells. Carcinogenisis 27: 1445-1453.

Vieira-Junior GM, Gonçalves TO, REgasini LO, Ferreira PMP, Pessoa C, Costa-Lotufo LV, Torres RB, Boralle N, Bolzani VS ANd CAVALHEIRO AJ. 2009. Cytotoxic clerodane diterpenoids from Casearia obliqua. J Nat Prod 72: 1847-1850.

WANG W, ZhaO J, WANG Y-H, SMILlie TA, Li X-C AND KHAN IA. 2009. Diterpenoids from Casearia sylvestris. Planta Med 75: 1436-1441.

WHO - World Health ORganization. 2003. Traditional Medicine, Fact sheet No. 134.

YAMAмото N ET AL. 1995. Regulatory mechanisms for production of IFN-g and TNF by antitumor T-cells or macrophages in the tumor-bearing state. J Immunol 154: 2281-2290.

ZHANG Y, VARCED SK AND NAIR MG. 2005. Human tumor cell growth inhibition by nontoxic anthocyanidins, the pigments in fruits and vegetables. Life Sci 76: 14651472 . 